\title{
SOCIAL PALLIATION
}

Canadian Muslims' Storied Lives on Living and Dying

Social Palliation is a pioneering study on living and dying as articulated by first-generation Iranian and Ismaili-Muslim communities in Canada. Using ethnographic narratives, Parin Dossa makes a case for a paradigm shift from palliative care to social palliation.

Experiences of displacement and resettlement reveal that life and death must be understood as an integrated unit if we are to appreciate what it is like to be awakened to our human existence. In the wake of structural exclusion and systemic suffering, social palliation brings to light displaced persons' endeavours to restore the integrity of life and death. Dossa highlights the point that death conjoined with life is embedded within the socio-cultural and spiritual experience. Here, a caring society is not perceived in fragments, as is the case with traditional institutional care or care offered during end-of-life. Rather, Dossa draws attention to an organic form of caring, illustrated through the trajectories of storied lives. In exemplifying more humane aspects of social palliation, this book foregrounds sacred traditions to illustrate their potential to evoke deep-level conversations across socio-political boundaries on what it is like to live and die in the contemporary world.

PARIN DOSSA is a professor of Anthropology at Simon Fraser University. 
This page intentionally left blank 
PARIN DOSSA

\section{Social Palliation}

Canadian Muslims' Storied Lives on Living and Dying 
(C) University of Toronto Press 2020

Toronto Buffalo London

utorontopress.com

Printed in the U.S.A.

ISBN 978-1-4875-0523-3 (cloth)

ISBN 978-1-4875-3180-5 (PDF)

ISBN 978-1-4875-2530-9 (paper)

ISBN 978-1-4875-3181-2 (EPUB)

\section{Library and Archives Canada Cataloguing in Publication}

Title: Social palliation : Canadian Muslims' storied lives on living and dying / Parin Dossa.

Names: Dossa, Parin Aziz, 1945- author.

Description: Includes bibliographical references and index.

Identifiers: Canadiana (print) 20200305743 | Canadiana (ebook)

20200305964 | ISBN 9781487505233 (hardcover) | ISBN 9781487525309

(softcover) | ISBN 9781487531805 (PDF) | ISBN 9781487531812 (EPUB)

Subjects: LCSH: Terminal care - Social aspects - Canada. | LCSH: Palliative treatment - Social aspects - Canada. | LCSH: Death - Social aspects Canada. | LCSH: Older Muslims - Care - Canada. | LCSH: Older immigrants - Care - Canada. | LCSH: Older Muslims - Canada - Social life and customs. | LCSH: Older immigrants - Canada - Social life and customs.

Classification: LCC HQ1073.5.C2 D67 2020 | DDC 306.9088297/0971-dc23

This book has been published with the help of a grant from the Federation for the Humanities and Social Sciences, through the Awards to Scholarly Publications Program, using funds provided by the Social Sciences and Humanities Research Council of Canada.

University of Toronto Press acknowledges the financial assistance to its publishing program of the Canada Council for the Arts and the Ontario Arts Council, an agency of the Government of Ontario.

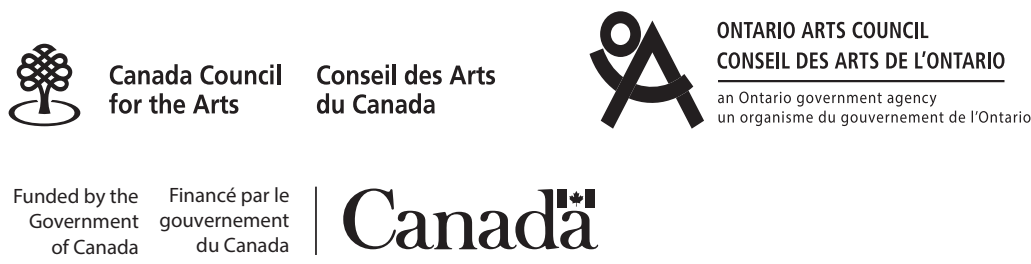




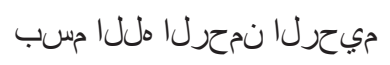

Bismi Llahi Al Rahmani Al Raheem

In the Name of Allah, the Compassionate, the Merciful 
This page intentionally left blank 